University of Wollongong

Research Online

Faculty of Engineering and Information

Faculty of Engineering and Information

Sciences - Papers: Part B

Sciences

2019

\title{
Numerical analysis of behavior of glass fiber-reinforced polymer bar- reinforced concrete beams under impact loads
}

\author{
Zein Saleh \\ University of Wollongong, zs492@uowmail.edu.au \\ M Neaz Sheikh \\ University of Wollongong, msheikh@uow.edu.au \\ Alex M. Remennikov \\ University of Wollongong, alexrem@uow.edu.au \\ Abheek Basu \\ University of Wollongong, abheek@uow.edu.au
}

Follow this and additional works at: https://ro.uow.edu.au/eispapers1

Part of the Engineering Commons, and the Science and Technology Studies Commons

Research Online is the open access institutional repository for the University of Wollongong. For further information contact the UOW Library: research-pubs@uow.edu.au 


\title{
Numerical analysis of behavior of glass fiber-reinforced polymer bar-reinforced concrete beams under impact loads
}

\author{
Abstract \\ This paper numerically investigates the behavior of glass fiber-reinforced polymer (GFRP) bar-reinforced \\ concrete beams (GFRP-RC beams) under low-velocity impact loads. A finite element model has been \\ developed and calibrated against the experimental investigation results of six GFRP-RC beams. The \\ results of the numerical analysis have been found in very good agreement with the experimental \\ investigation results. The finite element model captured the failure modes, crack profiles, midspan \\ deflection, impact and reaction forces, and dynamic strain of the GFRP-RC beams. Moreover, a parametric \\ study has been carried out to investigate the influence of the reinforcement ratio, compressive strength of \\ concrete, drop mass, drop velocity, and impact energy on the response of GFRP-RC beams under low- \\ velocity impact loads. It was found that the drop mass and velocity significantly influenced the damage \\ profiles of the beams, and the reinforcement ratio significantly influenced the midspan deflection and \\ reactions at the support.

\section{Disciplines} \\ Engineering | Science and Technology Studies

\section{Publication Details} \\ Saleh, Z., Sheikh, M., Remennikov, A. \& Basu, A. (2019). Numerical analysis of behavior of glass fiber- \\ reinforced polymer bar-reinforced concrete beams under impact loads. ACI Structural Journal, 116 (5), \\ 151-160.
}


Biography:

5 Zein Saleh is a PhD candidate at the school of Civil, Mining, and Environmental Engineering, 6 University of Wollongong, NSW, Australia. He received his BSc and MSc from the Lebanese 7 University, Lebanon in 2013. His research interests include FRP-RC beams, low-velocity 8 impact loads, and finite element modelling of RC beams under static and dynamic loads. Email:

9 zein@uow.edu.au

M. Neaz Sheikh is an Associate Professor in the School of Civil, Mining and Environmental Engineering, University of Wollongong. He received his BSc in civil engineering from Chittagong University of Engineering and Technology (CUET), Chittagong, Bangladesh, and his MPhil and PhD from the University of Hong Kong, China. His research interests include earthquake engineering, concrete structures, and composite structures. Email: msheikh@uow.edu.au $*$ Corresponding author

Alex Remennikov is an Associate Professor in the School of Civil, Mining and Environmental Engineering, University of Wollongong. He received his Bachelor of Engineering (Civil Engineering) and $\mathrm{PhD}$ from the National University of Construction and Architecture, Kiev, Ukraine. His research interests include response of structures to extreme loads and design of protective structures to resist effects of blast and impact. $\underline{\text { alexrem@uow.edu.au }}$

Abheek Basu is a Lecturer in the School of Mechanical, Materials, Mechatronic and Biomedical Engineering, University of Wollongong, NSW, Australia. He received his BE and $\mathrm{PhD}$ in Mechanical Engineering from the University of New South Wales (UNSW), Sydney, Australia. His research interests include computational solid mechanics, nonlinear material modelling and impact analysis. Email: abheek@uow.edu.au 
This paper investigates numerically the behavior of Glass Fibre Reinforced Polymer (GFRP) bar reinforced concrete beams (GFRP-RC beams) under low-velocity impact loads. A finite element model has been developed and calibrated against the experimental investigation results of six GFRP-RC beams. The results of the numerical analysis have been found in very good agreement with the experimental investigation results. The finite element model captured the failure modes, crack profiles, midspan deflection, impact and reaction forces, and dynamic strain of the GFRP-RC beams. Moreover, a parametric study has been carried out to investigate the influence of the reinforcement ratio, compressive strength of concrete, drop mass, drop velocity, and impact energy on the response of GFRP-RC beams under low-velocity impact loads. It was found that the drop mass and velocity significantly influenced the damage profiles of the beams and the reinforcement ratio significantly influenced the midspan deflection and reactions at the support.

Keywords: Reinforced concrete, Beam, GFRP, Impact, Modelling

\section{INTRODUCTION}

Fibre Reinforced Polymer (FRP) bars have emerged as one of the most suitable replacements for steel bars in Reinforced Concrete (RC) structures, especially in aggressive and corrosive environments. Glass FRP (GFRP) bars, in particular, have been popular and suitable for replacing steel bars in $\mathrm{RC}$ structures due to their availability, relatively low cost, and high ultimate strength. Recently, impact loads on structures and structural components have been receiving increasing research attention due to the increase in terrorist attacks worldwide. The response of Glass Fibre Reinforced Polymer bar Reinforced Concrete (GFRP-RC) beams under impact loads varies significantly from the response under static loads. Several studies investigated the response of GFRP-RC beams under static loads ${ }^{1-4}$ and Steel-RC beams under 
impact loads ${ }^{5-10}$. However, the response of GFRP-RC beams under impact loads has not been adequately investigated ${ }^{11,12}$. The key parameters (e.g. reinforcement ratio, concrete compressive strength, velocity of impact, and mass of the drop hammer) influencing the response of GFRP-RC beams under impact loads have not been thoroughly investigated.

Experiments carried out to investigate the response of GFRP-RC beams under impact loads are expensive. The finite element method has been widely used to model the behavior of RC beams under low-velocity (velocity less than $10 \mathrm{~m} / \mathrm{sec}[32.81 \mathrm{ft} / \mathrm{sec}]$ ) impact loads ${ }^{13-18}$. The finite element method is both cost and time efficient and is reliable in modelling the behavior of GFRP-RC beams under impact loads. There have been no numerical studies in the literature that investigated the response of GFRP-RC beams under low-velocity impact loads. The finite element program LS-DYNA ${ }^{19,20}$ has been one of the most popular codes to model the response of RC beams under low-velocity impact loads due to its comprehensive material library and ability to capture the non-linear response of RC beams under low-velocity impact loads. Hence, a comprehensive numerical investigation is carried out in this paper to understand the complex behavior of GFRP-RC beams under low-velocity impact loads.

\section{RESEARCH SIGNIFICANCE}

This study explores, through numerical analysis, the response of GFRP-RC beams under lowvelocity impact loads. An extensive parametric study has been carried out to investigate the effect of longitudinal reinforcement, compressive strength of concrete, drop mass, drop velocity, and impact energy on the response of GFRP-RC beams under impact loads. The results of this study will help in developing guidelines for the design of GFRP-RC beams under impact loads. Moreover, the experimental investigations will provide detailed data that can assist in the validation of future numerical and analytical studies. 
The finite element code LS-DYNA has been extensively used in the literature to model the behaviour of Steel-RC beams under impact loads ${ }^{14,16-18,21-27}$. The advantages of using LSDYNA include the efficient computational capability and the availability of a comprehensive material library.

\section{Structural geometry}

To account for the experimental conditions (presented in the next section), a three dimensional (3D) FE model was created. The full 3D FE model presented in Fig.1 accounts for the boundary conditions (roller and pinned supports) and for the loading conditions (drop hammer). To represent the concrete, supports, and drop hammer, eight-node solid hexahedron elements with single point integration were used. Single point integration produces a less stiff element and saves substantial computational time. However, an overhead of using one-point integration is the need to control the zero energy modes (hourglass modes) for the stability of the solution. In order to control and minimize the hourglass mode, Flanagan-Belytschklo hourglass control was chosen for the solid elements. The hourglass energy is presented in Fig.2, where it is calculated to be less than $0.3 \%$ of the total energy. To represent the GFRP bar for the reinforcement, 2D Hughes-Liu beam elements with 2x2 Gauss quadrature integration were used. A separate convergence study was carried out to select the appropriate mesh size. Mesh sizes of $20,15,10$, and $5 \mathrm{~mm}(0.787,0.59,0.393$, and $0.197 \mathrm{inch})$ were modelled and analysed. It was found that a mesh size of $10 \mathrm{~mm}(0.59$ inch and mesh aspect ratio of 1$)$ was the most suitable for this study. The decrease in the mesh size below $10 \mathrm{~mm}(0.59 \mathrm{inch})$ increased the computational time significantly with a minor influence on the accuracy of the results.

\section{Contact and boundary condition}

While several formulations are available in LS-DYNA to model the contact between the drop hammer beam, and supports, the automatic contact option was found to be sufficient for the 
current study. Pin and roller supports were used in order to replicate the boundary conditions of the experiment. The pin support restrained the movement and allowed the rotation about its major axis, whereas the roller support allowed translation and rotation about its major axis. The nodes located above the supports, on the top surface of the beam, were also restrained to prevent the uplift of the beam after the impact. Furthermore, the drop hammer was constrained to vertical movement in order to replicate the movement of the free-falling drop hammer. Moreover, taking the advantage of the symmetry, quarter models were used with appropriate symmetry boundary conditions to model the GFRP-RC beams in this study. In order to replicate the loading conditions, the drop hammer was set at a starting position $1 \mathrm{~mm}$ above the beam and was assigned an initial velocity $\mathrm{v}_{0}=\sqrt{2 \mathrm{gh}}$ (calculated from the condition of a free-falling body) where $g$ is the gravitational acceleration and $\mathrm{h}$ is the drop height. The self-weight of the beam, drop hammer, and gravitational acceleration were taken into account as well to replicate the experimental conditions. To avoid spurious oscillation at the contact surfaces, suitable viscous damping was specified for the model.

\section{Bond-slip model}

117 The bond between the GFRP bars and the concrete was modelled using a one-dimensional bond-slip model. A perfect bond was assumed between the concrete and the steel stirrups using merged nodes. The one-dimensional bond-slip model allows a set of nodes of the reinforcement (slave nodes) to slide along a set of nodes of the concrete (master nodes) via fictitious springs. Modelling the bond between the reinforcement and the concrete using a bond-slip model was used in previous research studies ${ }^{28-31}$. This contact model is an elastic-perfect-plastic model that requires input of the bond shear modulus $\left(\mathrm{G}_{\mathrm{s}}\right)$, maximum elastic slip $\left(s_{\max }\right)$, damage curve exponential coefficient $(h)$, and damage parameter $(D)$. The relationship of the elastic-perfectplastic model is given by Equation (1): 


$$
\boldsymbol{\tau}=\left\{\begin{aligned}
\mathbf{G}_{\mathbf{s}} \mathbf{S}, & \mathbf{s} \leq \mathbf{S}_{\max } \\
\tau_{\max } \mathbf{e}^{-\mathbf{h D},} & \mathbf{s}>\mathbf{s}_{\max }
\end{aligned}\right.
$$

Where $\tau$ is the bond shear stress of the GFRP bars.

\section{Modelling of materials}

\section{Concrete}

The Winfrith ${ }^{19}$ concrete model, chosen for this study, has been developed over many years by Broadhouse and Neilson ${ }^{32}$ and Broadhouse ${ }^{33}$. This model was developed to model structures subjected to blast and impact loads. This concrete model was validated extensively in the literature and its ability to capture the complex behaviour of RC structures under impact loads is well established ${ }^{25,34-39}$. An advantage of this concrete model is that a small number of input parameters required, including the density, initial tangent modulus $\left(\mathrm{E}_{\mathrm{c}}=4,700 \sqrt{\mathrm{f}_{\mathrm{c}}^{\prime}}\left[\right.\right.$ when $\mathrm{f}_{\mathrm{c}}^{\prime}$ is in $\mathrm{MPa}$ ] and $\mathrm{E}_{\mathrm{c}}=57,000 \sqrt{\mathrm{f}_{\mathrm{c}}^{\prime}}$ [when $\mathrm{f}_{\mathrm{c}}^{\prime}$ is in psi], as specified by $\mathrm{ACI}^{40}$ ), Poisson's ratio, uniaxial compressive and tensile strengths, and aggregate size of concrete. These parameters were determined in Goldston et al. ${ }^{11}$. The stress-strain diagram of the concrete is generated automatically by the Winfrith Concrete Model. Moreover, the Winfrith model has the ability to include strain rate effects and to generate crack growth algorithms. The additional binary output file includes information about the number, location, and width of the cracks. However, since the Winfrith model does not implicitly include an erosion criteria, an additional function was added such that, upon satisfying an appropriate failure criteria of concrete in compression, concrete elements were removed from the model.

\section{Reinforcement}

The Piecewise Linear Plasticity model ${ }^{19}$ was chosen to model the GFRP bar in this study. The input parameters for this model include the modulus of elasticity, Poisson's ratio, yield stress, tangent modulus, and plastic failure strain. This material model can be used for GFRP bars 
with an adequate choice of the input parameters. Fig.3 shows the stress-strain curve of a typical

149 GFRP bar using the Piecewise Linear Plasticity model. In order to replicate the behaviour GFRP bar behaviour, a tangent modulus value of zero (ETAN=0) is assigned, allowing an elastic-perfectly-plastic behaviour. The value of the ultimate strain is then chosen for the

152 pseudo-plastic strain in order for the GFRP bars to fail upon entering the plastic phase. Specifying those values ensures that the behaviour of GFRP bars is perfectly linear until the failure specified by the pseudo yield stress. Once the failure criteria is reached, the beam element is deleted from the calculation.

Supports and drop hammer

The steel supports and steel drop hammer were modelled using 'Rigid' model. An input of density, modulus of elasticity, and Poisson's ratio are required by this material model. Since the drop hammer and supports consisted of steel, the density and modulus of elasticity of steel were used in this material model.

\section{EXPERIMENTAL INVESTIGATION}

This section includes a description of the experiments carried out by the authors to investigate the impact response of six GFRP-RC beams. The full details of the impact experiment can be found in Goldston et al. ${ }^{11}$. For the purpose of completeness of the numerical analysis, a brief description of the experimental investigations is presented below.

A total of six GFRP-RC beams were tested under impact loads. The beams were designed in accordance with $\mathrm{ACI}^{40}$. One beam was designed as under-reinforced beam, one beam was designed as balanced beam, and four beams were designed as over-reinforced beams. These beams were chosen to investigate all three different types of failure modes. The beams were $100 \mathrm{~mm}(3.94 \mathrm{inch})$ in width, $150 \mathrm{~mm}(5.91 \mathrm{inch})$ in height, and $2400 \mathrm{~mm}(7.87 \mathrm{ft})$ in length 
with a clear concrete cover of $15 \mathrm{~mm}(0.591 \mathrm{inch})$. The clear span of the beam was $2000 \mathrm{~mm}$ (6.56 ft). The beams were divided into two main groups according to their concrete compressive strength. The compressive strengths of concrete at the day of testing for Groups A and $\mathrm{B}$ were $57.4 \mathrm{MPa}(8.33 \mathrm{ksi})$ and $72.3 \mathrm{MPa}(10.5 \mathrm{ksi})$ respectively. Moreover, each group included three GFRP-RC beams with different reinforcement arrangements. The number following the group name (A and B) indicates the type of reinforcement used in the GFRP-RC beams. The GFRP bars of diameters $6.35 \mathrm{~mm}$ (0.25 inch), $9.53 \mathrm{~mm}(0.375 \mathrm{inch})$, and $12.7 \mathrm{~mm}$ (0.5 inch) were used in the experiment. In the beam name, number 1 indicates that two GFRP bars of $6.35 \mathrm{~mm}(0.25 \mathrm{inch})$ diameter were used as longitudinal reinforcement, numbers 2 and 3 indicate that two GFRP bars of diameters 9.53 and $12.7 \mathrm{~mm}(0.375$ and 0.5 inch) each, respectively were used as longitudinal reinforcement. Beams with the numbers 1,2 , and 3 in the names had reinforcement ratios of $\rho_{f}=0.5 \%, 1 \%$, and $2 \%$, respectively. The compression reinforcement was similar to the tension reinforcement in all the GFRP-RC beams and consisted of two GFRP bars of the same diameter as those in tension. Steel bars of $4 \mathrm{~mm}(0.157$ inch) diameter spaced at $100 \mathrm{~mm}$ (3.94 inch) centre-to-centre were used as transverse reinforcement. The properties of the GFRP and steel bars were tested by the authors in Goldston et al. ${ }^{11}$, were presented in Table $\mathbf{1}$. The mass of the drop hammer used in the experimental investigations was $110 \mathrm{~kg}$ (243 lbs). The drop height was $1200 \mathrm{~mm}(3.94 \mathrm{ft})$ and could be assumed to be a free falling system without friction. The drop velocity was $4.85 \mathrm{~m} / \mathrm{s}(15.9 \mathrm{ft} / \mathrm{s})$ at impact. All the GFRP-RC beams were designed to fail in flexure (flexure-critical) with a shear-to-bending resistance ratio larger than one. The predicted failure modes according to $\mathrm{ACI}^{40}$ were balanced failure for Beam A1, under-reinforced failure for Beam B1, and overreinforced failure for the remaining beams (Beams A2, A3, B2, and B3). The midspan deflections were measured by a Laser-type Variable Displacement Transducer (LVDT) with a measuring range of $90 \mathrm{~mm}$ (3.54 inch). The strain in the GFRP bars was measured using strain 
gauges attached to the GFRP bars. In order to allow the strain gauges to be in direct contact with the GFRP bars, the sand coating on the GFRP bars was removed and the strain gauges were placed at the midspan of the GFRP bars. The impact and reaction forces were measured using load cells attached to the drop hammer and the supports. The variables of the experiment were the longitudinal reinforcement ratio and the compressive strength of concrete. The investigation aimed at understanding the behaviour of GFRP-RC beams under impact loads in terms of failure modes, midspan deflection, strain in GFRP bar, and impact and reaction forces.

To determine the values of the bond shear stress, maximum slip and damage coefficient, four specimens were tested under static loads according to RILEM ${ }^{41}$. All specimens were formed of two parts, as shown in Fig.4. Each specimen was formed of two parts separated by a distance of $50 \mathrm{~mm}$ (1.97 inch). Each part of the specimens was $100 \mathrm{~mm}$ (3.94 inch) in width, $180 \mathrm{~mm}$ (7.1 inch) in depth, and $375 \mathrm{~mm}(1.23 \mathrm{ft})$ in length. The embedment length used was six times the bar diameter according to Yan et. $\mathrm{al}^{42}$, as it provides a desirable failure. The diameters of the GFRP bars tested were $9.53 \mathrm{~mm}(0.375 \mathrm{inch})$ and $12.7 \mathrm{~mm}(0.5 \mathrm{inch})$. The specimens were tested using a $5000 \mathrm{kN}$ (1124 kips) Instron machine (Fig.4). The applied displacement was 1 $\mathrm{mm} / \mathrm{min}(0.0394 \mathrm{inch} / \mathrm{min})$. The displacement was applied until the failure of the bond between the GFRP bar and the concrete. The slip between the GFRP bars and the concrete was measured using LVDT's. The strains in the GFRP bars were measured using strain gauges attached to the GFRP bars.

\section{Failure modes}

As per the design codes $\mathrm{ACI}^{40}$ and $\mathrm{CSA}^{43}$, since GFRP bars do not yield, the preferred failure mode is concrete crushing in over-reinforced beams, which provides a warning prior to the collapse of the structure. The under-reinforced failure mode occurs due to GFRP bar rupture, 
whereas the balanced failure mode occurs due to simultaneous rupture of FRP bars and failure of concrete in compression. A brief description of the failure modes of the GFRP-RC beams is presented below.

\section{Under-reinforced and balanced failure}

224

The balanced Beam A1 and the under-reinforced Beam B1 failed due to the rupture of GFRP bars. The impact energy (1295 J) transferred to the beams from the drop hammer was sufficient to cause failure of the beam. The terms energy absorption capacity has been used by Adhikary et al. ${ }^{17,44}$ as the energy absorbed by the beam. The energy absorption capacity of the beam was calculated as the area under the load-midspan deflection curve from zero deflection until the midspan deflection corresponding to the maximum load. The energy absorption capacities of Beams $\mathrm{A} 1$ and $\mathrm{B} 1$ were $518 \mathrm{~J}$ and $435 \mathrm{~J}$, respectively. The beams started deflecting upon contact with the drop hammer and kept increasing until the GFRP bars ruptured. The cracks were predominantly flexural cracks which started developing and propagating vertically upwards until the failure of the beam. The beams were then split into two parts at the impact zone. Moreover, a local failure was observed, which was due to the spalling of concrete in the impact zone.

\section{Over-reinforced failure}

The over-reinforced Beams A2, A3, B2, and B3 failed due to concrete crushing. The impact energy (1295 J) of the first drop was not sufficient to cause failure of the beams. The beams returned to their initial position showing an elastic behaviour indicating reserve capacity. Shear cracking was evident at the impact area with the crushing of the concrete cover. The cracks observed in these beams were flexural cracks in addition to shear cracks. The flexural cracks propagated vertically upwards and were observed in the areas closer to the supports. In the impact area, on the other hand, the cracks were predominantly shear cracks with the shear plug 
developing at the impact zone. Shear plug failure was observed in these beams with cracks originating from the impact zone and propagating at 45 degrees angle. Moreover, all beams showed shear cracks regardless of the reinforcement ratio and compressive strength of concrete. It was also observed, however, that as the reinforcement ratio and compressive strength of concrete increased, the number of shear cracks in the beams decreased.

The midspan deflection was measured for all the beams under impact loads. For the Beams A1 and B1, the midspan deflection was not recorded since the beams completely failed and were split into two parts. For the remaining over-reinforced beams, all beams started deflecting from zero to reach a maximum midspan deflection after about 25 milliseconds. The beams then rebounded and returned to their initial state within 60 milliseconds with a parabolic trace of the midspan deflection-time curve. Moreover, beams with higher reinforcement ratios and concrete compressive strengths experienced lower maximum midspan deflections.

\section{Dynamic strain in GFRP bar}

The dynamic strains in the GFRP bars were measured using strain gauges attached to the bars at the midspan. The dynamic strains in the GFRP bars started from zero and increased with a high strain rate at the beginning where the response of the beam was still elastic. After cracks started to develop (approximately at 3 milliseconds), the rate of the development of the dynamic strain was decreased. The dynamic strain kept increasing with some fluctuations until reaching the maximum dynamic strain when the maximum midspan deflection was reached.

264 The dynamic strain then dropped after the beam rebounded to its initial position. Moreover, the dynamic strains were not measured in Beams A1 and B1 due to the rupture of the GFRP bars. 
267 The forces during an impact are the impact force, reaction forces, and inertia forces. The impact force equals the sum of the inertia forces and reaction forces. All beams showed a similar shape for these forces. The impact force was generated upon the contact between the drop hammer and the GFRP-RC beam. This impact force was demonstrated by a high magnitude impulse (approximately $200 \mathrm{kN}$ [45 kips]) over a short duration of time (10 milliseconds) representing the contact between the drop hammer and the beam. The recorded inertia force was similar to the impact force for this duration. The reaction forces recorded were zero due to the delay in the travel of the stress wave from the impact point to the supports. The total reaction forces of both supports (reaction force hereafter) then started resisting the impact force until the end of the impact (approximately 60 milliseconds). Also, after almost 15 milliseconds from the start of the impact, the reaction force matched the impact force (at around $30 \mathrm{kN}$ [6.75 kips]) while the inertia force was negligible.

\section{Bond-slip}

Table 2 presents the results of the bond-slip tests carried out in this study. The averages of the maximum shear bond stresses for the GFRP bars with diameters $9.53 \mathrm{~mm}(0.375$ inch $)$ and $12.7 \mathrm{~mm}(0.5 \mathrm{inch})$ were $38.45 \mathrm{MPa}(5.6 \mathrm{ksi})$ and $31.3 \mathrm{MPa}$ (4.5 ksi), respectively. Moreover, the averages of the slip at maximum stresses for the GFRP bars with diameters $9.53 \mathrm{~mm}(0.375$ inch) and $12.7 \mathrm{~mm}(0.5 \mathrm{inch})$ were $0.14 \mathrm{~mm}(0.0055 \mathrm{inch})$ and $0.11 \mathrm{~mm}(0.0043 \mathrm{inch})$, respectively. Furthermore, the averages of the exponential decays for the GFRP bars with diameters $9.53 \mathrm{~mm}(0.375 \mathrm{inch})$ and $12.7 \mathrm{~mm}(0.5 \mathrm{inch})$ were 0.11 and 0.15 , respectively. These values were used in the numerical bond-slip model of the GFRP bars with concrete in this study. However, due to the unavailability of the GFRP bars with diameter $6.35 \mathrm{~mm}(0.25$ inch) during the testing of the bond-slip, the values were taken to be the same as those of the 
the bond strength increases with the decrease of the bar diameter. Hence, using the bond properties of the GFRP bar with a diameter of $9.53 \mathrm{~mm}(0.375 \mathrm{inch})$ to model the GFRP bar with a diameter of $6.35 \mathrm{~mm}(0.25$ inch $)$ was considered conservative.

\section{COMPARISONS OF THE FINITE ELEMENT MODEL AND EXPERIMENTAL}

\section{RESULTS}

The FE model was validated against the experimental results. The validation was carried out in terms of the failure modes, midspan deflection, strain in GFRP bar, and impact forces. The numerical results seem to be in good agreement with the experimental results. A brief description of the results is presented below.

\section{Failure modes}

The FE models created with LS-DYNA show the ability to capture the experimental behaviour of the GFRP-RC beams under impact loads. In terms of the general failure mode, beams that were under-reinforced and balanced (Beams B1 and A1) failed due to GFRP bar rupture, as predicted. Fig.5 presents the failure of Beam A1 (only Beam A1 was chosen for presentation purposes since Beam B1 had a similar failure mode). It is evident from Fig.5 that Beam A1 failed due to the rupture of the GFRP bars. The concrete spalling at the midspan was captured by the high-speed video camera and by the FE model as well. The cracks were predominantly flexural cracks originating from the tension side of the beam and propagating vertically upwards. The FE model was able to capture those cracks in addition to the GFRP bar rupture, which caused the failure of the beam.

Moreover, the four over-reinforced beams failed due to concrete crushing. Concrete crushing was observed along with shear cracks originating from the impact zone and propagating at $45^{\circ}$. Fig.6 shows the damage profile of Beam A2 (only Beam A2 was chosen for presentation purposes since the damage profile of Beam A2 is similar to Beams A3, B2, and B3). The cracks 
in the beam were flexural cracks that developed away from the impact area and shear cracks concentrated in the vicinity of the impact area. However, the shear cracks were larger and more dominant. The local damage at the impact area was also captured by the FE model.

\section{Midspan deflection}

The midspan deflection in the experiment was analysed and the midspan deflection-time curves were plotted. These curves were compared against the results of the FE model. For the underreinforced and balanced beams, the midspan deflection was not captured due to the rupture of the GFRP bars, which split the beam into two parts. Therefore, only the results of the overreinforced beams were compared in this section. All four over-reinforced beams followed a parabolic midspan deflection-time curve. The deflections of the GFRP-RC beams started when the drop hammer impacted the beams. The beams accelerated at the midspan vertically downwards until reaching the maximum midspan deflection. The velocity measured at the maximum midspan deflection was zero. The beams then rebounded and came back to the initial position within a timeframe of 60 milliseconds. The midspan deflection-time curves of Beams A2, A3, B2, and B3 were presented in Fig.7. The experimental and numerical results seem to be in good agreement with each other. The parabolic shape at the midspan deflection was captured by the FE model. The response time (time from beginning of impact until the beams of the maximum midspan deflections were in very good agreement. A comparison of the maximum midspan deflection values is presented in Table 3. It was observed from Table 3 that the midspan deflection results of the numerical analysis match very well with the numerical-to-experimental midspan deflections was presented in Table 3. The numerical analysis over-predicts the midspan deflection of the GFRP-RC beams by an average of $3 \%$. 
341 The experimental dynamic strain in the GFRP bar was measured by strain gauges placed on

342 the midspan of the GFRP bar. The experimental and numerical results of the dynamic strain

343 were presented in Fig.8 (only Beam A3 was chosen for presentation purposes, since all four

344 over-reinforced beams had a similar shape of the dynamic strain-time curves). The experimental dynamic strain of the under-reinforced and balanced beams was not available due to the failure of the GFRP bars. The dynamic strains in the GFRP bar started at zero and increased with a high strain rate. The strain rate decreased once the cracking of concrete started. The dynamic strain kept increasing with some fluctuations until reaching the maximum dynamic strain when the maximum midspan deflection was reached. The dynamic strain then dropped again after the beam returned to its initial position. The overall shapes and values of the numerical dynamic strains match that of the experiment very well. The initial increase at a high rate, the decrease after cracking of concrete, the fluctuation, and reaching a maximum value when the maximum midspan deflection is reached were all captured by the FE model.

Table 3 also presents the numerical and experimental values of the maximum dynamic strain. The values of the dynamic strain using the numerical analysis were $2 \%$ higher than the experimental values.

\section{Impact and reaction forces}

The numerical and experimental forces compared in this section are the impact force and the reaction force. All beams showed a similar shape for both forces. The impact force is attributed initially with a high magnitude impulse over a short duration of time. This impact force then drops back to zero before having a second peak and then fluctuates until going back to zero at the end of the response. The reaction force lags behind the impact force. Fig.9 shows the experimental and numerical response of Beam A2 in terms of the impact force and reaction of supports (only Beam A2 was chosen for presentation purposes since all the over-reinforced 
beams have similar impact force and reaction force shapes). The results seem to be in very good agreement in terms of the overall shape, duration, and mean values of the impact and reaction forces. Moreover, Table 3 presents the numerical and experimental values of the areas over-predicts the values of the impact force and reaction force by $6 \%$ and $7 \%$, respectively.

\section{PARAMETRIC STUDY}

A parametric study was carried out to investigate the effect of the reinforcement ratio, compressive strength of concrete, drop height, drop mass, and impact energy. The beams were $200 \mathrm{~mm}$ (7.87 inch) in width, $300 \mathrm{~mm}$ (11.81 inch) in height, and $2400 \mathrm{~mm}$ (7.87 ft) in length with $2000 \mathrm{~mm}$ (6.56 ft) clear span. Moreover, the modulus of elasticity of the GFRP bars was $50 \mathrm{GPa}(7251 \mathrm{ksi})$ and the ultimate strength was $1200 \mathrm{MPa}(174 \mathrm{ksi})$. The bond-slip model was taken into account with a maximum slip of $0.15 \mathrm{~mm}$ (0.006 inch), bond shear modulus of 111 $\mathrm{MPa} / \mathrm{mm}$ (41 ksi/inch), and exponential decay of 0.12 . The findings of this study are important for developing guidelines for the design of GFRP-RC beams under impact loads. The development of design guidelines and the development of an analytical model is considered beyond the scope of this paper.

\section{Influence of the longitudinal reinforcement ratio}

To investigate the effect of the longitudinal reinforcement ratio, six GFRP-RC beams were modelled under low-velocity impact loads. The reinforcement ratios of the six beams were $0.5 \%, 1 \%, 1.5 \%, 2 \%, 2.5 \%$, and $3 \%$. All six beams in this study had shear reinforcement comprised of $8 \mathrm{~mm}(0.31 \mathrm{inch})$ diameter bars spaced at $100 \mathrm{~mm}$ (3.94 inch) centre-to-centre ensuring flexure-critical design failure. The compressive strength of concrete for the beams 
the beam at $5 \mathrm{~m} / \mathrm{s}(16.4 \mathrm{ft} / \mathrm{s}$ [drop height of $1.3 \mathrm{~m}(11.8 \mathrm{inch})])$. The impact energy was calculated as $5000 \mathrm{~J}$.

391

392

393

The results show that, as the reinforcement ratio of the GFRP-RC beams increased, the maximum midspan deflection and the maximum dynamic strain in the GFRP bars at the midspan decreased, whereas the reaction force increased. Fig.10 presents the maximum midspan deflection, maximum dynamic strain in GFRP bars at midspan, and maximum reaction force as a function of the reinforcement ratio. The maximum midspan deflection decreased from $40.52 \mathrm{~mm}$ (1.6 inch) to $20.17 \mathrm{~mm}$ (0.79 inch) upon increasing the reinforcement ratio from $0.5 \%$ to $3 \%$ (Fig.10 (a)). This 50\% decrease in the maximum midspan deflection was also associated with a $50 \%$ decrease in the time to reach the maximum midspan deflection (from $19 \mathrm{~ms}$ to $9.8 \mathrm{~ms}$ ). Moreover, the maximum dynamic strain in the GFRP bars at the midspan significantly reduced from 0.016 to 0.0053 upon increasing the reinforcement ratio from $0.5 \%$ to $3 \%$ (Fig.10 (b)). As observed from Fig.10 (c), the impact force was not affected by the increase in the reinforcement ratio, whereas the reaction force increased. This is due to the impact force being influenced by the drop mass, drop height, and contact surfaces, whereas the reaction force depended on the energy absorbed by the beam and the inertia forces. The resistance of the beam increased with an increase in the longitudinal reinforcement ratio.

\section{Influence of the compressive strength of concrete}

To investigate the effect of the compressive strength of concrete, five GFRP-RC beams were modelled under low-velocity impact load. The compressive strengths of concrete were $30 \mathrm{MPa}$ (4.35 ksi), $40 \mathrm{MPa}(5.8 \mathrm{ksi}), 50 \mathrm{MPa}(7.25 \mathrm{ksi}), 60 \mathrm{MPa}(8.7 \mathrm{ksi})$, and $70 \mathrm{MPa}(10.5 \mathrm{ksi})$. The impact mass was $400 \mathrm{~kg}(882 \mathrm{lbs})$ and the drop velocity was $5 \mathrm{~m} / \mathrm{s}(16.4 \mathrm{ft} / \mathrm{s}$ [5000 J impact energy]). The beams in this study and all the studies that follow had a longitudinal reinforcement ratio of $1 \%$ and $8 \mathrm{~mm}(0.31 \mathrm{inch})$ shear reinforcement spaced at $100 \mathrm{~mm}(3.94$ inch) centre-to-centre. 
414 The results showed that, as the compressive strength of concrete increased, the maximum

415 midspan deflection decreased. The maximum midspan deflection decreased by $10 \%$ upon 416 increasing the compressive strength of concrete from $30 \mathrm{MPa}$ to $70 \mathrm{MPa}$ (4.35 ksi to $10.5 \mathrm{ksi}$ ).

417 The compressive strength of concrete had a minor influence on the maximum dynamic strain 418 at the midspan of the GFRP bars. Moreover, the impact and reaction forces increased with an 419 increase in the compressive strength of concrete. A $57 \%$ increase in the reaction force was 420 observed when the compressive strength of concrete increased from $30 \mathrm{MPa}$ to $70 \mathrm{MPa}$ (4.35 ksi to $10.5 \mathrm{ksi}$ ). This means that the resistance of the beam increases with an increase in the compressive strength of concrete.

\section{Influence of the drop mass}

To investigate the effect of the drop mass on the response of GFRP-RC beams under lowvelocity impact loads, five different drop masses were investigated. The masses were $200 \mathrm{~kg}$ (441 lbs), $300 \mathrm{~kg}$ (661 lbs), $400 \mathrm{~kg}$ (882 lbs), $500 \mathrm{~kg}$ (1102 lbs), and $600 \mathrm{~kg}$ (1323 lbs). All the impact velocities were fixed to $5 \mathrm{~m} / \mathrm{s}(16.4 \mathrm{ft} / \mathrm{s})$. The compressive strength of concrete in this study and the studies that follow was $40 \mathrm{MPa}(5.8 \mathrm{ksi})$.

It was observed that the drop mass significantly influenced the crack profile of the GFRP-RC beams. When the drop mass was $200 \mathrm{~kg}$ (441 lbs), only flexural cracks were observed propagating vertically upwards from the bottom of the beam. As the mass increased, more shear cracks were observed propagating at an angle of $45^{\circ}$. At a mass higher than $600 \mathrm{~kg}(1323 \mathrm{lbs})$, shear cracks appear to dominate the failure of the beams. Moreover, maximum midspan deflection and the maximum dynamic strain in the GFRP bars increased by $127 \%$ and $89 \%$, respectively when the drop mass increased from $200 \mathrm{~kg}(441 \mathrm{lbs})$ to $600 \mathrm{~kg}$ (1323 lbs). The drop mass had a relatively lower influence on the impact and reaction forces. The impact and $\mathrm{kg}(1323 \mathrm{lbs})$. 


\section{Influence of the drop velocity}

440 To investigate the effect of the drop mass on the response of GFRP-RC beams under low441 velocity impact loads, five different drop velocities were investigated. The impact velocities 442 were $3 \mathrm{~m} / \mathrm{s}(9.8 \mathrm{ft} / \mathrm{s}), 4 \mathrm{~m} / \mathrm{s}(13.1 \mathrm{ft} / \mathrm{s}), 5 \mathrm{~m} / \mathrm{s}(16.4 \mathrm{ft} / \mathrm{s}), 6 \mathrm{~m} / \mathrm{s}(19.7 \mathrm{ft} / \mathrm{s})$, and $7 \mathrm{~m} / \mathrm{s}(23 \mathrm{ft} / \mathrm{s})$. 443 The impact mass was $400 \mathrm{~kg}$ (882 lbs).

444 Similar observations to those reported in the above section were observed upon increasing the 445 impact velocity. The maximum midspan deflection and maximum dynamic strain in the GFRP 446 bars increased by $162 \%$ and $113 \%$, respectively when the drop velocity increased from $3 \mathrm{~m} / \mathrm{s}$ 447 to $7 \mathrm{~m} / \mathrm{s}(9.8 \mathrm{ft} / \mathrm{s}$ to $23 \mathrm{ft} / \mathrm{s})$. The impact force was significantly influenced by the drop velocity 448 where an increase from $3 \mathrm{~m} / \mathrm{s}$ to $7 \mathrm{~m} / \mathrm{s}(9.8 \mathrm{ft} / \mathrm{s}$ to $23 \mathrm{ft} / \mathrm{s})$ led to a $160 \%$ increase in the impact 449 force and a $45 \%$ increase in the reaction force. Also, the crack profile was influenced by the 450 drop velocity. When the drop velocity was $3 \mathrm{~m} / \mathrm{s}(9.8 \mathrm{ft} / \mathrm{s})$, flexural cracks developed 451 propagating vertically in the beam. Upon increasing the drop velocity to $7 \mathrm{~m} / \mathrm{s}(23 \mathrm{ft} / \mathrm{s})$, shear cracks propagating at $45^{\circ}$ dominated the beam.

\section{Influence of the impact energy}

454 To investigate the effect of the drop mass and drop velocity on the response of GFRP-RC beams under low-velocity impact loads, the impact energy of this study was fixed to $5000 \mathrm{~J}$. The drop masses chosen for this study were $200 \mathrm{~kg}$ (441 lbs), $300 \mathrm{~kg}$ (661 lbs), $400 \mathrm{~kg}$ (882 lbs), $500 \mathrm{~kg}(1102 \mathrm{lbs})$, and $600 \mathrm{~kg}(1323 \mathrm{lbs})$. The drop velocities of these masses were 7.07 $\mathrm{m} / \mathrm{s}(23.2 \mathrm{ft} / \mathrm{s}), 5.77 \mathrm{~m} / \mathrm{s}(18.9 \mathrm{ft} / \mathrm{s}), 5 \mathrm{~m} / \mathrm{s}(16.4 \mathrm{ft} / \mathrm{s}), 4.47 \mathrm{~m} / \mathrm{s}(14.7 \mathrm{ft} / \mathrm{s})$, and $4.08 \mathrm{~m} / \mathrm{s}(13.4$ $\mathrm{ft} / \mathrm{s}$ ), respectively. This ensured that all the drop tests had an impact energy of $5000 \mathrm{~J}$. The aim of this study is to investigate the effect of increasing the mass while decreasing the velocity of the drop hammer on the response of the GFRP-RC beams. 
It was observed that varying the drop mass and drop velocity while keeping the impact energy fixed has a significant influence on the failure mode of the GFRP-RC beams. Fig.11 presents the damage profiles of two beams impacted with the same impact energy using different drop masses and velocities. The damage profiles are presented at $5 \mathrm{~ms}$ and $20 \mathrm{~ms}$. In Fig.11 (a), when the drop velocity was low and the drop mass was high $(4.08 \mathrm{~m} / \mathrm{s}[13.4 \mathrm{ft} / \mathrm{s}]$ and $600 \mathrm{~kg}$ [1323 lbs]), flexural cracks dominated in the first 5 milliseconds. Shear cracks developed after the flexural cracks. However, in Fig.11 (b), when the beam was impacted with high drop velocity and low drop mass $(7.07 \mathrm{~m} / \mathrm{s}[23.2 \mathrm{ft} / \mathrm{s}]$ and $200 \mathrm{~kg}$ [441 lbs]), shear cracks dominated throughout the whole response. Also, it was observed that the drop mass influenced the maximum midspan deflection and the dynamic strain in the GFRP bars, whereas the drop velocity influenced the impact and reaction forces. The maximum midspan deflection and the dynamic strain in the GFRP bars increased by $22 \%$ and $18 \%$, respectively when the drop mass increased from $200 \mathrm{~kg}$ (441 lbs) to $600 \mathrm{~kg}$ (1323 lbs) while keeping the impact energy fixed at $5000 \mathrm{~J}$. Moreover, the impact and reaction forces increased by $42 \%$ and $20 \%$, respectively when the drop velocity increased from 4.08 to $7.07 \mathrm{~m} / \mathrm{s}$ [13.4 to $23.2 \mathrm{ft} / \mathrm{s}$ ] while keeping the impact energy fixed at $5000 \mathrm{~J}$.

\section{CONCLUSIONS}

479 The test results of six GFRP-RC beams were used to calibrate a finite element model to investigate the behaviour of GFRP-RC beams under low-velocity impact loads. The finite element model captured the midspan deflections, dynamic strains in the GFRP bars, impact force, reaction force, crack patterns, and failure modes. After calibrating the finite element model, a comprehensive parametric study was carried out to investigate the influence of the longitudinal reinforcement ratio, compressive strength of concrete, drop mass, drop velocity, 
and impact energy on the behaviour of GFRP-RC beams under low-velocity impact loads. The following conclusions were drawn:

487

1. The maximum midspan deflection and maximum dynamic strain in GFRP bars decreased significantly with an increase in the longitudinal reinforcement ratio. Moreover, the impact force and crack profile were not influenced by variation of the longitudinal reinforcement ratio, whereas the reaction force increased with an increase in the longitudinal reinforcement ratio.

2. The maximum midspan deflection decreased with an increase in the compressive strength of concrete. Moreover, the maximum dynamic strain in the GFRP bars was not influenced by the compressive strength of concrete, whereas the impact and reaction forces increased leading to a higher resistance of the beam with an increase in the compressive strength of concrete.

3. The drop mass significantly influenced the crack and damage profiles of the beams. More shear cracks developed when the drop mass increased. At high masses (600 kg [1323 $\mathrm{lbs}]$ ), shear cracks appeared to dominate the failure of the beam. Moreover, the maximum midspan deflection and maximum dynamic strain in the GFRP bars significantly increased when the drop mass increased.

4. The drop velocity significantly influenced the crack and damage profiles of the beams. Flexural cracks were observed at low impact velocities (3-4 m/s [9.84-13.1 ft/s]), whereas shear cracks dominated in higher velocities $(6-7 \mathrm{~m} / \mathrm{s}[19.7-23 \mathrm{ft} / \mathrm{s}])$. The maximum midspan deflection, maximum dynamic strain in the GFRP bars, impact force, and reaction force significantly increased with an increase in the drop velocity.

5. A combination of low drop velocity and high drop mass $(4.08 \mathrm{~m} / \mathrm{s}[13.4 \mathrm{ft} / \mathrm{s}]$ and 600 $\mathrm{kg}$ [1323 lbs]) led to flexural cracks at the beginning of the impact followed by shear cracks. However, a combination of high drop velocity and low drop mass $(7.07 \mathrm{~m} / \mathrm{s}$ [23.2 
$\mathrm{ft} / \mathrm{s}$ ] and $200 \mathrm{~kg}$ [441 lbs]) led to shear cracks dominating throughout the whole impact duration. Also, it was observed that the drop mass significantly influenced the maximum midspan deflection and the maximum dynamic strain in the GFRP bars, whereas the drop velocity significantly influenced the impact and reaction forces.

\section{ACKNOWLEDGMENTS}

The authors express their gratitude to the University of Wollongong for providing the funding and facilities for the experimental and numerical work presented in this paper.

\section{REFERENCES}

1. Alsayed S, Al-Salloum Y, Almusallam T, "Performance of glass fiber reinforced plastic bars as a reinforcing material for concrete structures," Composites Part B: Engineering, V. 31, No. 6. 2000, pp. 555-67.

2. Toutanji HA, Saafi M, "Flexural behavior of concrete beams reinforced with glass fiberreinforced polymer (GFRP) bars," ACI Structural Journal, V. 97, No. 5. 2000, pp. 712-9. 3. Ashour A, "Flexural and shear capacities of concrete beams reinforced with GFRP bars," Construction and Building Materials, V. 20, No. 10. 2006, pp. 1005-15.

\section{El-Mogy M, El-Ragaby A, El-Salakawy E, "Effect of transverse reinforcement on the} flexural behavior of continuous concrete beams reinforced with FRP," J Compos Constr, V. 15, No. 5. 2011, pp. 672-81.

5. Kishi N, Mikami H, Matsuoka K, Ando T, "Impact behavior of shear-failure-type RC beams without shear rebar," International Journal of Impact Engineering, V. 27, No. 9. 2002, pp. 955-68.
6. Fujikake et al. K, "Impact response of reinforced concrete beam and its analytical evaluation," Journal of Structural Engineering, V. 135, No. 8. 2009, pp. 938-50.

\section{Saatci S, Vecchio FJ, "Effects of shear mechanisms on impact behavior of reinforced} concrete beams," ACI Structural Journal, V. 106, No. 1. 2009, pp. 78-86. 8. Kishi N, Mikami H, "Empirical formulas for designing reinforced concrete beams under impact loading," ACI Structural Journal, V. 109, No. 4. 2012, pp. 509-19.

\section{Fujikake K, Li B, Somraj A, "Influence of Loading Rate on Shear Capacity of Reinforced} Concrete Beams," Int J Prot Struct, V. 4, No. 4. 2013. 

beams," ACI Structural Journal, V. 111, No. 3. 2014, pp. 651-60. 11. Goldston M, Remennikov A, Sheikh MN, "Experimental investigation of the behaviour of concrete beams reinforced with GFRP bars under static and impact loading," Engineering Structures, V. 113. 2016, pp. 220-32. 12. Goldston M, Remennikov A, Sheikh MN, "Flexural behaviour of GFRP reinforced high strength and ultra high strength concrete beams," Construction and Building Materials, V. 131. 2017, pp. 606-17.

13. Daudeville L, Malécot Y, "Concrete structures under impact," European Journal of Environmental and Civil Engineering, V. 15, No. sup1. 2011, pp. 101-40. 14. Kishi N, Khasraghy SG, Kon-No H, "Numerical simulation of reinforced concrete beams under consecutive impact loading," ACI Structural Journal, V. 108, No. 4. 2011, pp. 444-52. 15. Ožbolt J, Sharma A, "Numerical simulation of reinforced concrete beams with different shear reinforcements under dynamic impact loads," International journal of impact engineering, V. 38, No. 12. 2011, pp. 940-50. 16. Adhikary SD, Li B, Fujikake K, "Low Velocity impact response of reinforced concrete beams: Experimental and numerical investigation," Int J Prot Struct, V. 6, No. 1. 2015, pp. 81-111.

17. Adhikary et al. SD, "Residual resistance of impact-damaged reinforced concrete beams," Mag Concr Res, V. 67, No. 7. 2015, pp. 364-78. 18. Zhao D-B, Yi W-J, Kunnath SK, "Shear Mechanisms in Reinforced Concrete Beams under Impact Loading," Journal of Structural Engineering, V. 143, No. 9. 2017, pp. 04017089. 19. Hallquist JO, "LS-DYNA keyword user's manual," Livermore Software Technology Corporation, Livermore, California 94551, Livermore, California 94551. 2017a. 20. Hallquist JO, "LS-DYNA theory manual," Livermore software Technology corporation, Livermore, California 94551, V. 3. 2017 b.

21. Adhikary SD, Li B, Fujikake K, "Parametric study of RC beams under a wide range of loading rates," Proceedings of the Institution of Civil Engineers: Structures and Buildings, V. 168, No. 10. 2015, pp. 729-46.

22. Jiang H, Zhao J, "Calibration of the continuous surface cap model for concrete," Finite Elements in Analysis and Design, V. 97. 2015, pp. 1-19. Struct Stab Dyn. 2016, pp. 1750053. 
24. Liao W, Li M, Zhang W, Tian Z, "Experimental studies and numerical simulation of behavior of RC beams retrofitted with HSSWM-HPM under impact loading," Engineering Structures, V. 149. 2017, pp. 131-46.

25. Jiang H, Chorzepa MG, "An effective numerical simulation methodology to predict the impact response of pre-stressed concrete members," Eng Fail Anal, V. 55. 2015, pp. 63-78. 26. Bhatti et al. AQ, "Elasto-plastic impact response analysis of shear-failure-type RC beams with shear rebars," Materials \& Design, V. 30, No. 3. 2009, pp. 502-10.

27. Jiang H, Wang X, He S, "Numerical simulation of impact tests on reinforced concrete beams," Mater Des, V. 39. 2012, pp. 111-20.

28. Pham AT, Tan KH, Yu J, "Numerical investigations on static and dynamic responses of reinforced concrete sub-assemblages under progressive collapse," Engineering Structures, V. 149. 2017, pp. 2-20.

29. Shi Y, Li Z-X, Hao H, "Bond slip modelling and its effect on numerical analysis of blastinduced responses of RC columns," Struct Eng Mech, V. 32, No. 2. 2009, pp. 251-67.

30. Xu S, Wu C, Liu Z, Li J, "Numerical study of ultra-high-performance steel fibrereinforced concrete columns under monotonic push loading," Advances in Structural Engineering, V. 21, No. 8. 2018, pp. 1234-48

31. Bao Y, Lew HS, Kunnath SK, "Modeling of reinforced concrete assemblies under column-removal scenario," Journal of Structural Engineering, V. 140, No. 1. 2012, pp. 04013026.

32. Broadhouse B, Neilson A, "Modelling reinforced concrete structures in dyna3d," Book Modelling reinforced concrete structures in dyna3d, UKAEA Atomic Energy Establishment, 1987.

33. Broadhouse B, "The Winfrith concrete model in LS-DYNA3D," Report: SPD/D (95), V. 363. 1995.

34. Abu-Odeh A, "Modeling and Simulation of Bogie Impacts on Concrete Bridge Rails using LS-DYNA®," Book Modeling and Simulation of Bogie Impacts on Concrete Bridge Rails using LS-DYNA®, 2008, pp. 8-10.

35. Schwer L, "Modeling rebar: the forgotten sister in reinforced concrete modeling," Book Modeling rebar: the forgotten sister in reinforced concrete modeling, 2014.

36. Algaard W, Lyle J, Izatt C, "Perforation of composite floors," Book Perforation of composite floors, 2005, pp. 1123-30. 
37. Wu Y, Crawford JE, Magallanes JM, "Performance of LS-DYNA concrete constitutive models," Book Performance of LS-DYNA concrete constitutive models, in $12^{\text {th }}$ International LS-DYNA users conference, 2012, pp. 3-5.

38. Thai D-K, Kim S-E, "Failure analysis of reinforced concrete walls under impact loading using the finite element approach," Eng Fail Anal, V. 4. 2014, pp. 252-77.

39. Thiagarajan G, Kadambi AV, Robert S, Johnson CF, "Experimental and finite element analysis of doubly reinforced concrete slabs subjected to blast loads," International Journal of Impact Engineering, V. 75. 2015, pp. 162-73.

40. ACI, "Guide for the Design and Construction of Structural Concrete Reinforced with Fiber-Reinforced Polymer (FRP) Bars (ACI 440.1R-15)," Book Guide for the Design and Construction of Structural Concrete Reinforced with Fiber-Reinofrced Polymer (FRP) Bars (ACI 440.1R-15), American Concrete Institute, Farmington Hills, MI 48331, 2015. 41. RILEM, "RILEM technical recommendations for the testing and use of construction materials." London SE1 8HN: Spon; 1994.

42. Yan F, Lin Z, Yang M, "Bond mechanism and bond strength of GFRP bars to concrete: a review," Composites Part B: Engineering, V. 98. 2016, pp. 56-69.

43. CSA, "Design and construction of building structures with fibre-reinforced polymers." Canadian Standards Association; 2012.

44. Adhikary SD, Li B, Fujikake K, "Dynamic behavior of reinforced concrete beams under varying rates of concentrated loading," International Journal of Impact Engineering, V. 47, Sep. 2012, pp. 24-38.

45. Achillides Z, Pilakoutas K, "Bond behavior of fiber reinforced polymer bars under direct pullout conditions," J Compos Constr, V. 8, No. 2. 2004, pp. 173-81.

46. Okelo R, Yuan RL, "Bond strength of fiber reinforced polymer rebars in normal strength concrete," J Compos Constr, V. 9, No. 3. 2005, pp. 203-13.

(1)

(1)


636 List of Tables:

637 Table 1-Properties of the GFRP and steel reinforcement used in the experiment (Goldston et $\left.638 \mathrm{al}^{11}\right)$

639 Table 2- Bond-slip results of the tested GFRP bars

640 Table 3- Numerical versus experimental results of GFRP-RC beams

641

642 List of Figures:

643 Fig.1-3D model of the GFRP-RC beam

644 Fig.2- Stability of the solution - Hourglass Energy

645 Fig.3 - Numerical stress-strain curve for GFRP reinforcement bar

646 Fig.4- Bond-slip test of the GFRP-RC specimens (Dimensions in $\mathrm{mm} .1 \mathrm{~mm}=0.0394 \mathrm{inch}$ )

647 Fig.5- Failure mode of balanced GFRP-RC beam (Beam A1)

648 Fig.6- Damage profile of over-reinforced GFRP-RC beam (Beam A2)

649 Fig.7-Midspan deflection-time curves: (a) Beam A2 (b) Beam A3 (c) Beam B2 (d) Beam B3

650 Fig.8 - Dynamic strain-time curve at the midspan of GFRP bar (Beam A3)

651 Fig.9- Numerical and experimental forces (Beam B2): (a) Impact (b) Reaction

652 Fig.10 - Influence of reinforcement ratio on: (a) maximum midspan deflection (b) maximum 653 dynamic strain (c) maximum reaction force

654 Fig.11- Crack profile of beams with constant impact energy at different stages of impact 
659

660

661

Table 1- Properties of the GFRP and steel reinforcement used in the experiment (Goldston et al $^{11}$ )

\begin{tabular}{|c|c|c|c|c|}
\hline $\begin{array}{c}\text { Type of } \\
\text { reinforcement bar }\end{array}$ & $\begin{array}{c}\text { Diameter of the } \\
\text { reinforcement bar } \\
(\mathrm{mm})\end{array}$ & $\begin{array}{c}\text { Modulus of } \\
\text { elasticity } E_{f} \\
(\mathrm{GPa})\end{array}$ & $\begin{array}{c}\text { Tensile } \\
\text { strength } f_{u} \\
(\mathrm{MPa})\end{array}$ & $\begin{array}{c}\text { Rupture strain } \\
(\%)\end{array}$ \\
\hline GFRP & 6.35 & 37.5 & 732 & 1.96 \\
\hline GFRP & 9.53 & 55.6 & 1764 & 3.18 \\
\hline GFRP & 12.7 & 48.6 & 1605 & 3.30 \\
\hline Steel & 4 & 200 & 500 & N/A \\
\hline
\end{tabular}

Note: $1 \mathrm{~mm}=0.0394$ inch, $1 \mathrm{MPa}=145 \mathrm{psi}, 1 \mathrm{GPa}=145 \mathrm{ksi}$, The fiber volume fraction of GFRP bars was $70 \%$

Table 2- Bond-slip results of the tested GFRP bars

\begin{tabular}{|c|c|c|c|c|}
\hline Sample tested & 1 & 2 & 3 & 4 \\
\hline Bar diameter (mm) & \multicolumn{2}{|c|}{9.53} & \multicolumn{2}{|c|}{12.7} \\
\hline Maximum bond stress (MPa) & 39.87 & 37.02 & 29.02 & 33.57 \\
\hline Slip at maximum stress (mm) & 0.18 & 0.10 & 0.11 & 0.11 \\
\hline Exponential decay & 0.12 & 0.10 & 0.14 & 0.16 \\
\hline Average bond stress (MPa) & \multicolumn{2}{|c|}{38.45} & \multicolumn{2}{|c|}{31.3} \\
\hline Average slip (mm) & \multicolumn{2}{|c|}{0.14} & \multicolumn{2}{|c|}{0.11} \\
\hline Average exponential decay & \multicolumn{2}{|c|}{0.11} & \multicolumn{2}{|c|}{0.15} \\
\hline
\end{tabular}

$$
\text { Note: } 1 \mathrm{~mm}=0.0394 \text { inch, } 1 \mathrm{MPa}=145 \mathrm{psi}
$$




\begin{tabular}{|c|c|c|c|c|c|c|c|c|c|c|c|c|}
\hline \multirow{2}{*}{ Beam name } & \multicolumn{4}{|c|}{ Numerical } & \multicolumn{4}{c|}{ Experimental } & \multicolumn{3}{c|}{ Numerical/Experimental } \\
\cline { 2 - 15 } & $\begin{array}{c}\Delta_{m} \\
(\mathrm{~mm})\end{array}$ & $\varepsilon_{f r p}$ & $\begin{array}{c}J_{I} \\
(\mathrm{~N} . \mathrm{sec})\end{array}$ & $\begin{array}{c}J_{R} \\
(\mathrm{~N} . \mathrm{sec})\end{array}$ & $\Delta_{m}$ & $\varepsilon_{f r p}$ & $\begin{array}{c}J_{I} \\
(\mathrm{~N} . \mathrm{sec})\end{array}$ & $\begin{array}{c}J_{R} \\
(\mathrm{~N} . \mathrm{sec})\end{array}$ & $\Delta_{m}$ & $\varepsilon_{f r p}$ & $J_{I}$ & $J_{R}$ \\
\hline A2 & 59.1 & 0.99 & 964 & 911 & 57.5 & 0.96 & 901 & 799 & 1.03 & 1.03 & 1.07 & 1.14 \\
\hline A3 & 53.3 & 0.74 & 952 & 898 & 52.3 & 0.73 & 914 & 872 & 1.02 & 1.01 & 1.04 & 1.03 \\
\hline B2 & 52.8 & 0.96 & 901 & 865 & 51.6 & 0.96 & 847 & 833 & 1.02 & 1 & 1.06 & 1.04 \\
\hline B3 & 46.8 & 0.71 & 976 & 927 & 43.8 & 0.68 & 931 & 874 & 1.07 & 1.04 & 1.05 & 1.06 \\
\hline
\end{tabular}

$* \Delta_{m}$ : maximum midspan deflection, $\varepsilon_{f r p}$ : dynamic strain in the GFRP bars, $J_{I}$ : area under the impact force, $J_{R}$ : area under the reaction force. Note: $1 \mathrm{~mm}=0.0394 \mathrm{inch}, 1 \mathrm{~N}=0.225 \mathrm{lb}$

665

666 


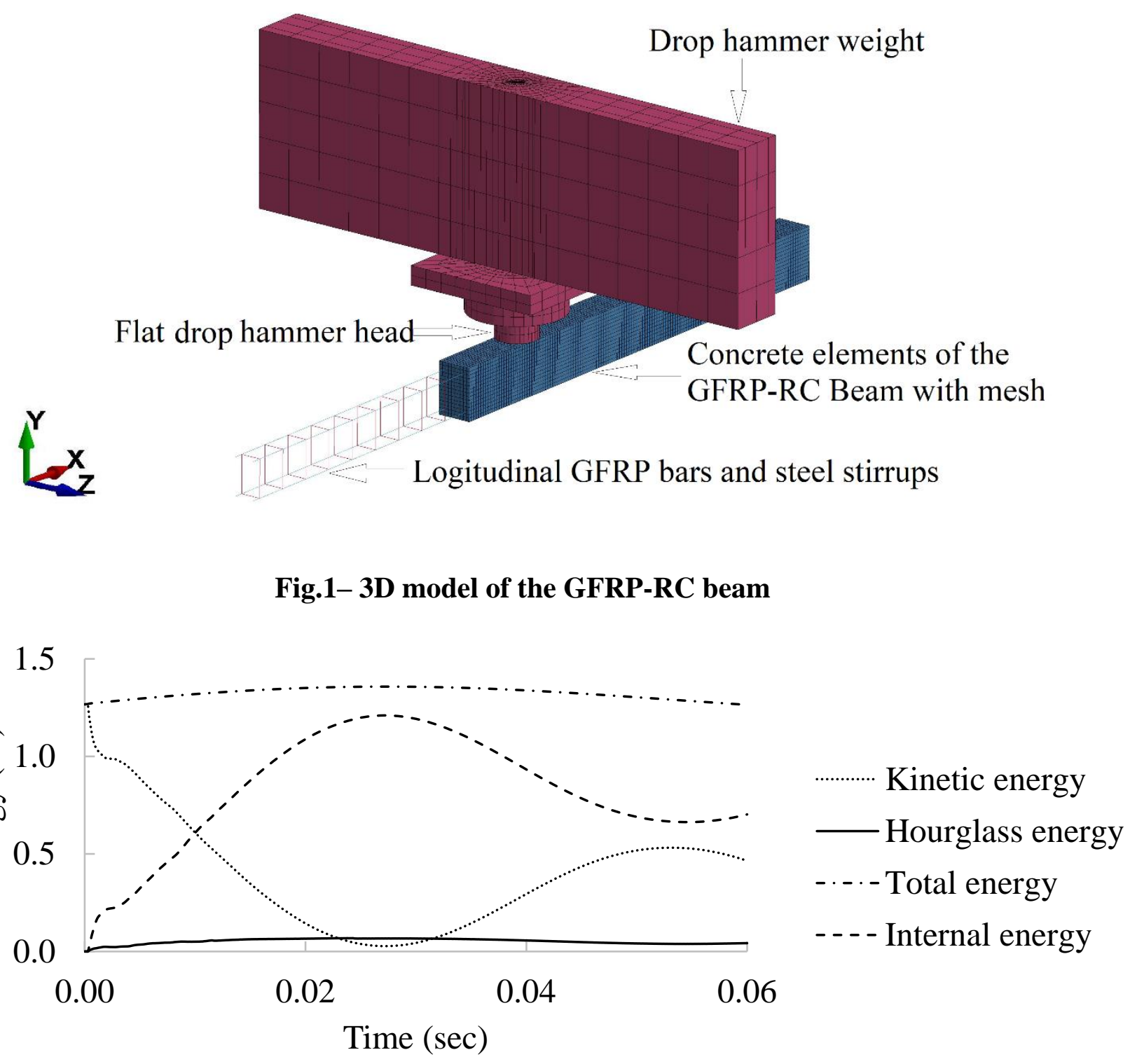

670

671

Fig.2- Stability of the solution - Hourglass energy

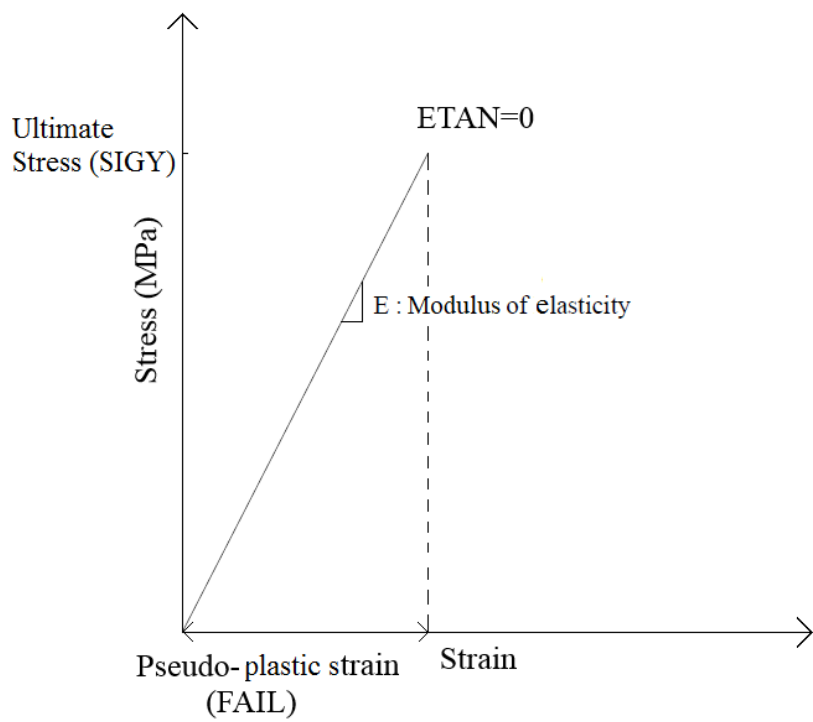



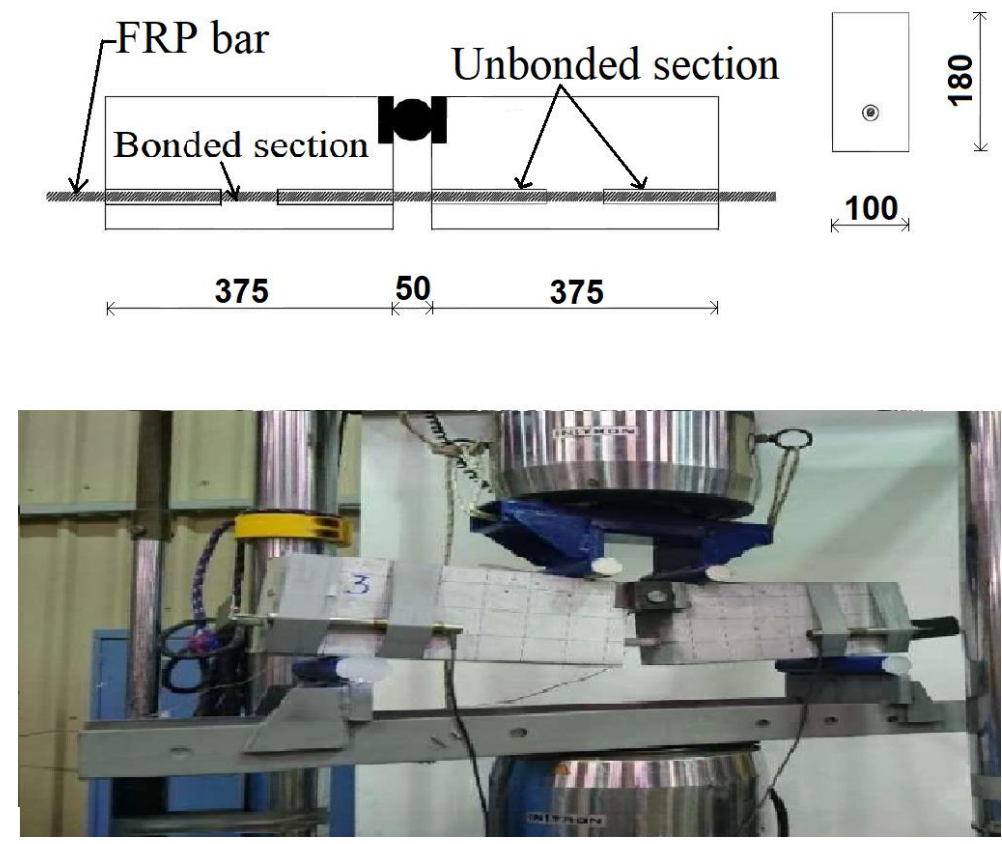

675 Fig.4- Bond-slip test of the GFRP-RC specimens (Dimensions in $\mathbf{~ m m . ~} 1 \mathbf{~ m m}=\mathbf{0 . 0 3 9 4}$ inch)
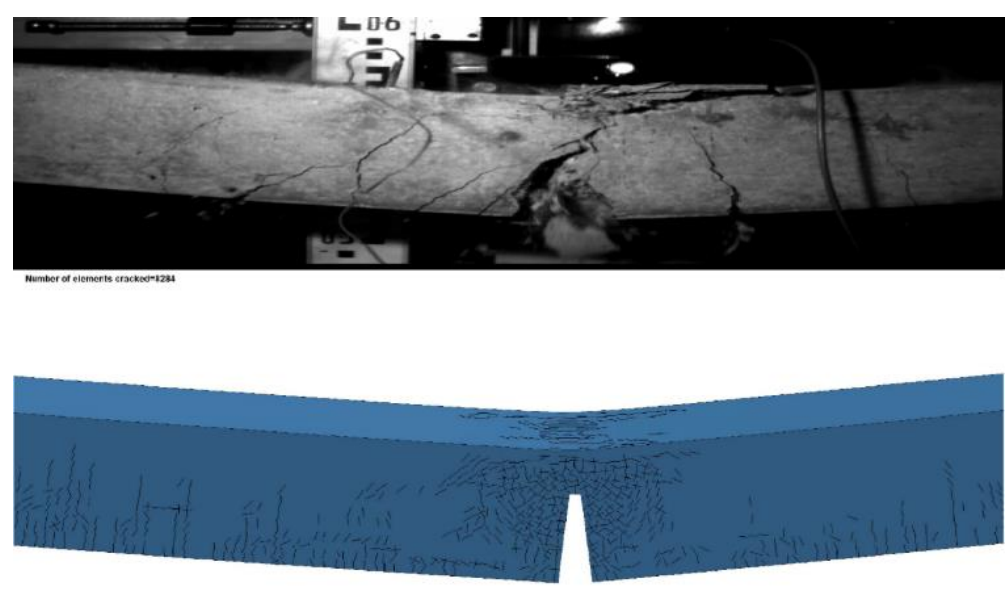

676

677

Fig.5- Failure mode of balanced GFRP-RC beam (Beam A1)

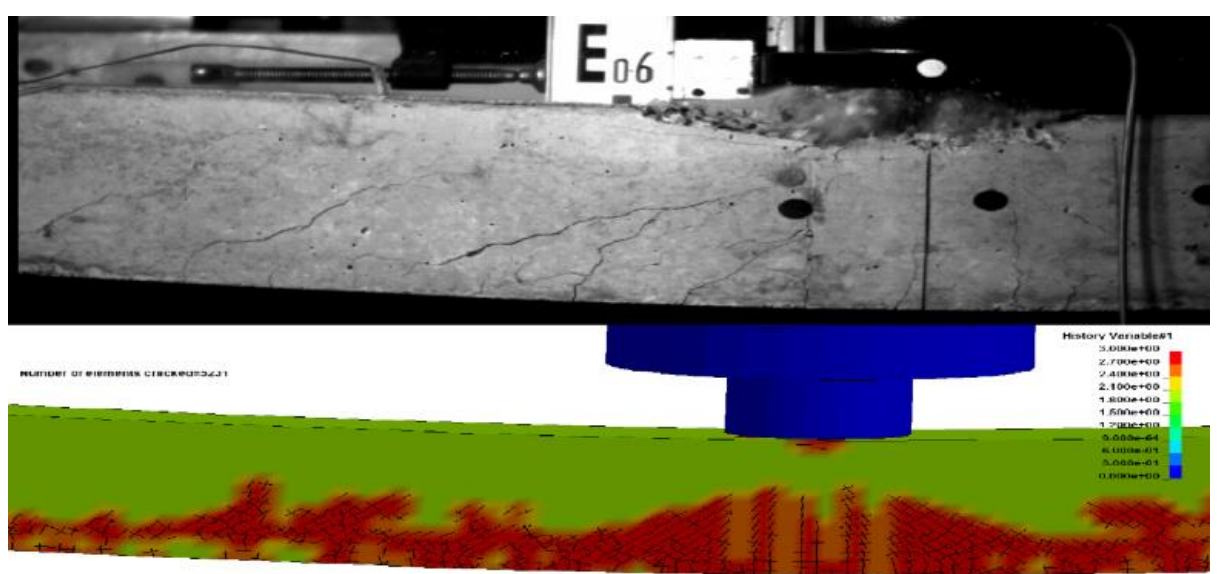




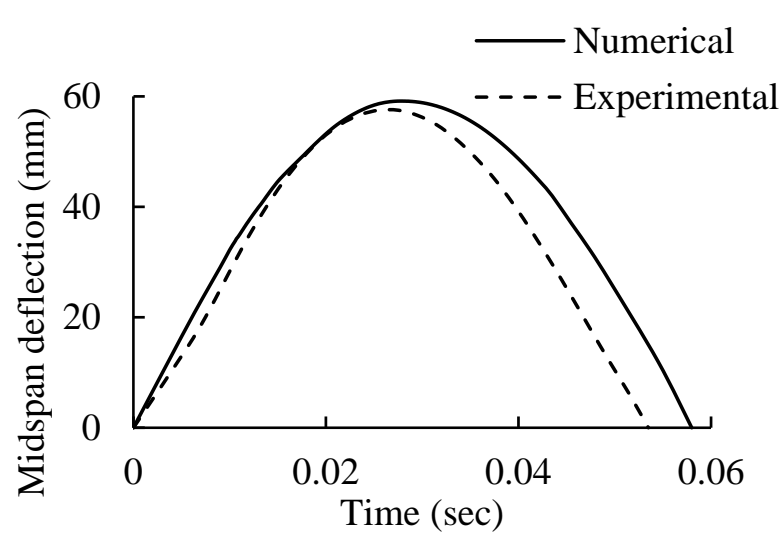

(a)

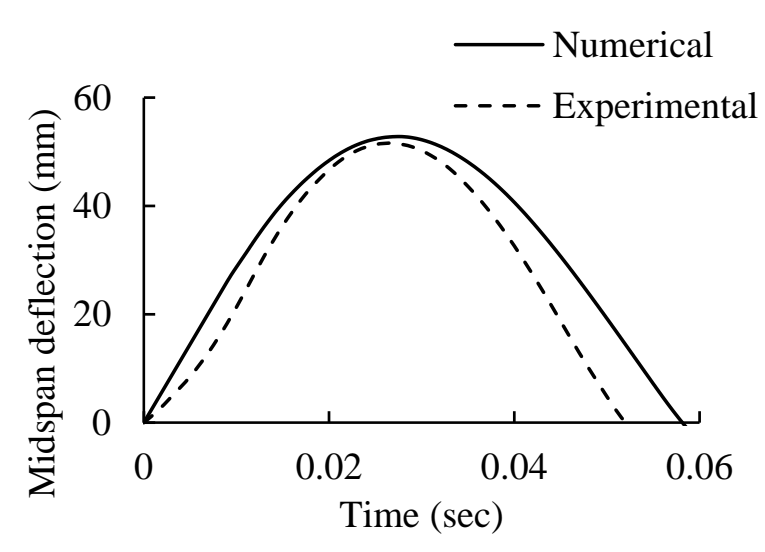

(c)

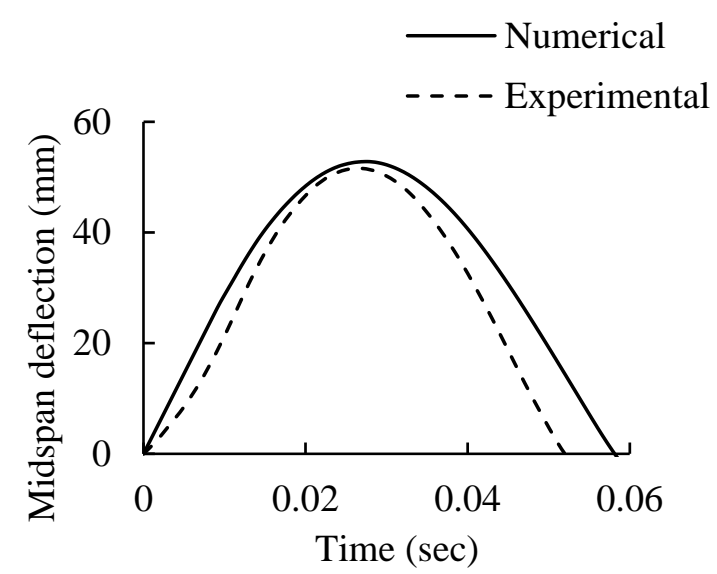

(b)

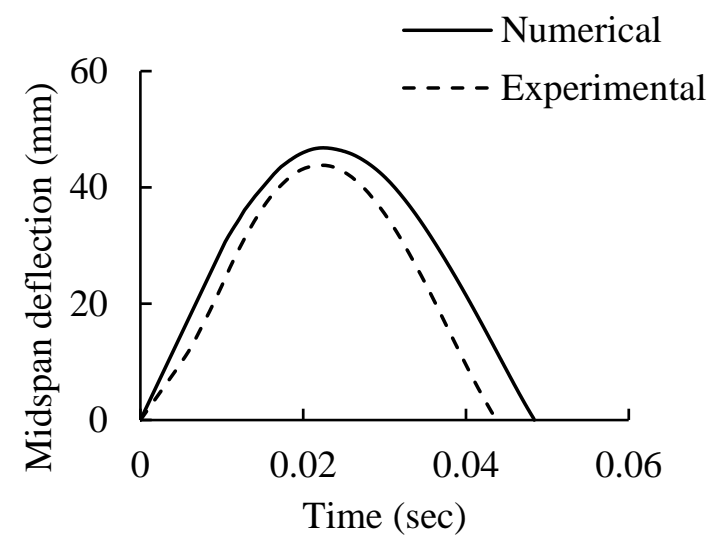

(d)

Fig.7- Midspan deflection-time curves:(a) Beam A2 (b) Beam A3 (c) Beam B2 (d) Beam B3

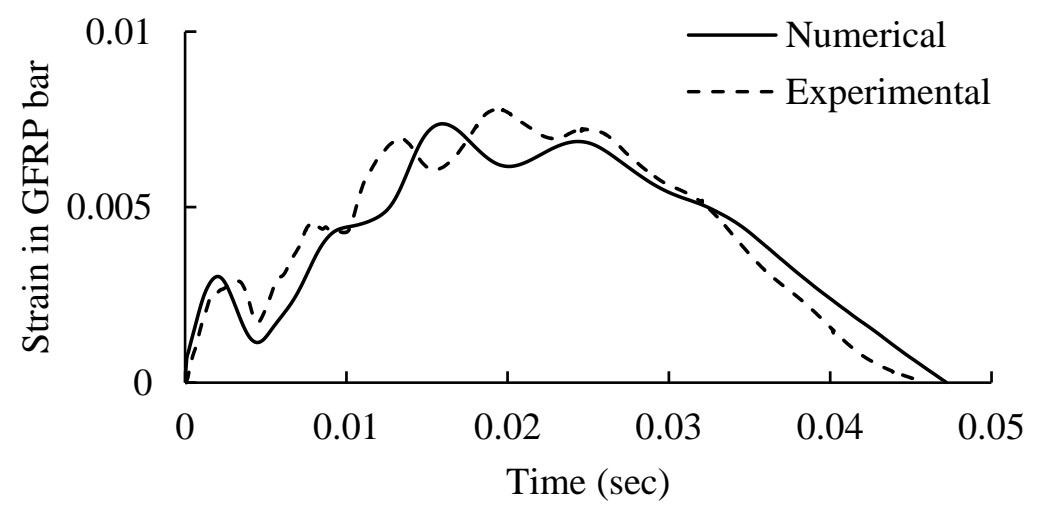

680 


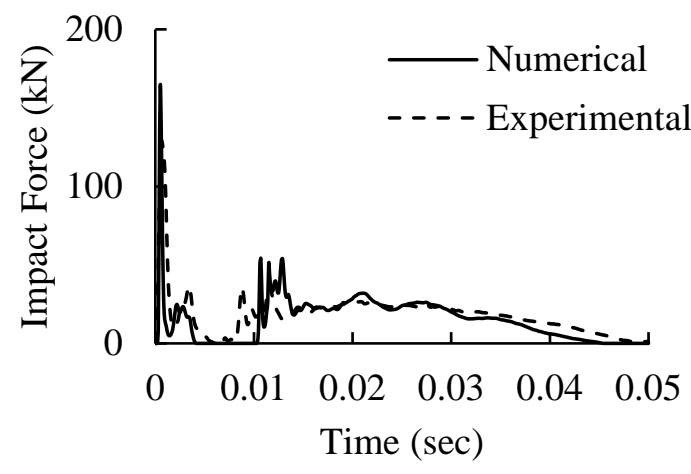

(a)

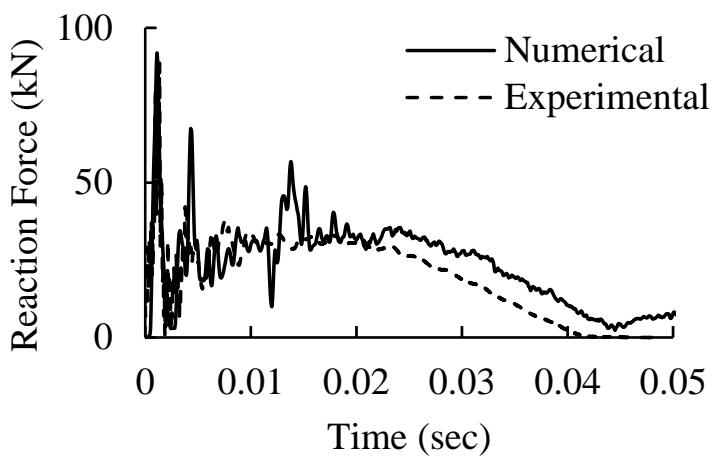

(b)

Fig.9- Numerical and experimental forces (Beam B2): (a) Impact (b) Reaction

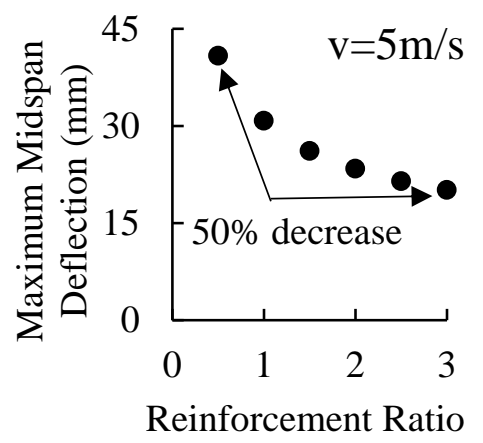

$(\%)$

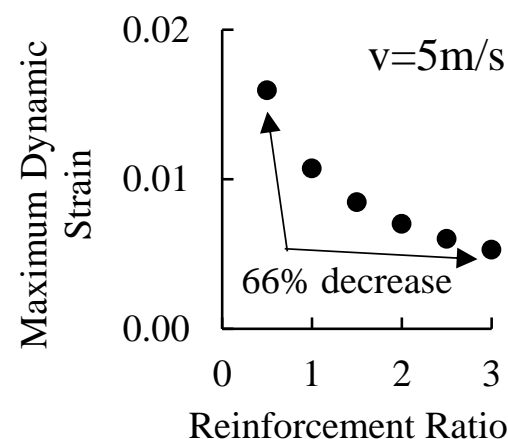

$(\%)$

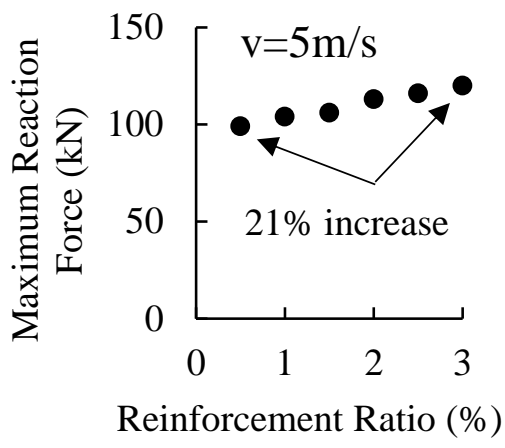

(c)

(a)

(b)

Fig.10 - Influence of reinforcement ratio on: (a) maximum midspan deflection (b) maximum dynamic strain (c) maximum reaction force (impact velocity $=5 \mathrm{~m} / \mathrm{s}$ )
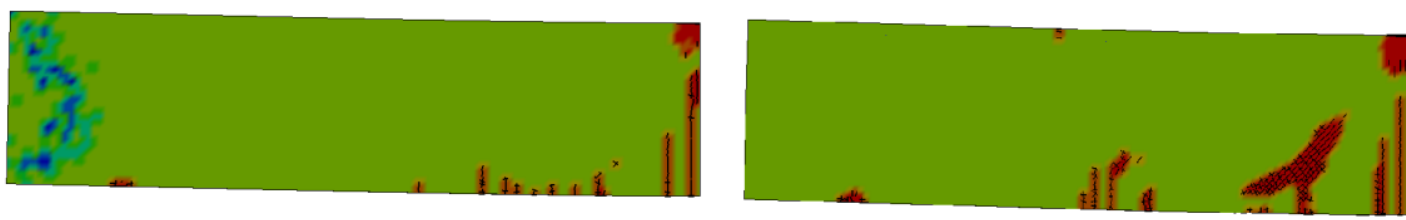

History Variable\#1

$3.000 \mathrm{e}+00$

$2.700 \mathrm{e}+00$

$2.400 \mathrm{e}+00$

$2.100 \mathrm{e}+00$

$1.800 \mathrm{e}+00$

$1.500 \mathrm{e}+00$

$1.200 \mathrm{e}+00$

9.000e-01

$6.000 \mathrm{e}-01$

$3.000 \mathrm{e}-01$

$0.000 e+00$

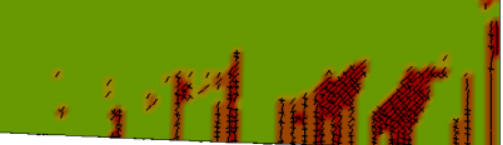

(a)

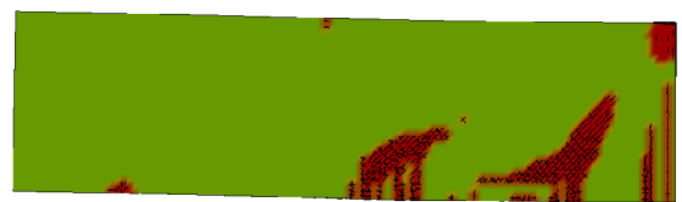

(b)

Fig.11- Crack profile of beams impacted with a constant impact energy at $5 \mathrm{~ms}$ and $20 \mathrm{~ms}$ (a) $4.08 \mathrm{~m} / \mathrm{s}(13.4 \mathrm{ft} / \mathrm{s})$ and $600 \mathrm{~kg}(1323 \mathrm{lbs})($ b) $7.07 \mathrm{~m} / \mathrm{s}(23.2 \mathrm{ft} / \mathrm{s})$ and $200 \mathrm{~kg}(441 \mathrm{lbs})$ 